\title{
PARTICULATE BIOGENIC SILICA IN THE EUPHOTIC ZONE OFF SOUTHERN CALIFORNIA
}

\section{SILICE PARTICULADO BIOGENICO EN LA CAPA EUFOTICA EN EL AREA COSTERA FRENTE AL SUR DE CALIFORNIA}

\author{
Elizabeth Orellana 1 \\ Edward H. Renger 1 \\ James R. Nelson 2 \\ Richard W. Eppley 2 \\ Institute of Marine Resources \\ Scripps Institution of Oceanography \\ University of California, San Diego \\ La Jolla, California 92093, U.S.A. \\ 1 Dirección permanente: Facultad de Ciencias Marinas \\ Universidad Autónoma de Baja California \\ Apartado Postal 453, Ensenada, Baja California, México \\ 2 Dirección permanente: Skidaway Institute of Oceanography \\ P.O. Box 13687, Savannah, Georgia 31416, U.S.A.
}

Orellana, E., Renger, H.E., Nelson, R.J. and Eppley, W.R. (1990). Particulate biogenic silica in the euphotic zone off southern California. Sílice particulado biogénico en la capa eufótica en el área costera frente al sur de California. Ciencias Marinas, 16(1):69-89.

\begin{abstract}
Particulate biogenic silica (PSi) in suspended matter was measured over depth in the euphotic zone during five cruises in the Southern California Bight from May 1985 to January 1987. PSi decreased offshore, as do other measures of phytoplankton biomass. The mean molar ratio of PSi/POC was 0.047 , similar to that in other oligotrophic regions. PSi was also compared with particulatc nitrogen, chlorophyll and fucoxanthin concentrations, resulting in mean ratios PSi/PON 0.32 (by moles), PSi/chlorophyll $a 0.85$ (moles/gram), and PSi/fucoxanthin 3.6 (moles/gram). Estimates of depth integrated PSi production rates were low, with mean value 2.2 $m$ mole $m^{-2} d^{-1}$. It was concluded that, for this oligotrophic region, particulate organic silica is related to subsurface chlorophyll maximum. In general, particulate organic silica levels are low.
\end{abstract}

\section{RESUMEN}

En la capa eufótica de las aguas costeras en la región adyacente al sur de California, se estimó el sílice biogénico (PSi) en material suspendido durante cinco cruceros de mayo de 1985 a enero de 1987. El PSi disminuyó al alejarse de la costa así como otras medidas de biomasa. La razón PSi/POC fue 0.047, similar a los resultados encontrados en otras regiones oligotróficas. Los valores de PSi fueron comparados con las concentraciones de nitrógeno particulado, clorofila y ficoxantina, resultando valores de razones promedio de PSi/PON de 0.32 (por mol), PSi/clorofila $a$ de 0.85 (moles/gramo) y PSi/ficoxantina de 3.6 (moles/gramo). Las estimaciones de las tasas de producción PSi integradas para la capa eufótica fueron hajas, con valores promedio de $2.2 \mathrm{~m}$ moles m $\mathrm{m}^{-2} \mathrm{~d}^{-1}$. Se concluye que en esta región oligotrófica, el sílice orgánico particulado es bajo y que se relaciona con el máximo de clorofila subsuperficial. 


\section{INTRODUCTION}

Primary production and phytoplankton biomass have been measured in the Southern California Bight since 1974 (Eppley and Holm-Hansen, 1986). A goal of this work has been to develop information and understanding of biogeochemical cycling in the upper waters. The elements carbon and nitrogen have been emphasized to date, in relation to new and regenerated primary production. Recently, particulate biogenic silica (PSi) has also been measured. The objective is to assess PSi standing stock and production rates in the euphotic zone relative to carbon and nitrogen.

Phytoplankton production and its fate in the ocean are important for the global biogeochemical cycles of the elements, including the element silicon (Berger, 1976; Broecker and Peng, 1982; Spencer, 1983). The deep waters of the eastern North Pacific have the highest dissolved $\mathrm{Si}$ concentrations in the world's oceans (Berger, 1976; Broecker and Peng, 1982) yet dissolved silicic acid concentrations are only $1-5 \mu \mathrm{M}$ above the nutricline in the oligotrophic waters of the Bight.

Satellite thermal images of the California Current show that cold (and nutrientrich) waters in the upwelling areas off northern and central California extend south beyond Point Conception and the Channel Islands while warm (and nutrient-poor) water is found in the Southern California Bight. Here, cold water plumes, when found, are within a few kilometers of shore and are of short duration, e.g. a week or less (Jackson, 1986). Satellite images of chlorophyll and related pigments show low chlorophyll concentrations in the Bight (Smith and Baker, 1982; Carlucci et al., 1986; Pelaez and McGowan, 1986). Nutrient and primary production spatial and temporal variability suggest that oligotrophic conditions are the rule in the Bight with strong interannual, seasonal and event-scale variations (summarized in Eppley and Holm-Hansen, 1986).

\section{MATERIALS AND METHODS}

\section{Sampling}

Data are reported for five cruises in the Southern California Bight. Cruise dates were

\section{INTRODUCCION}

En el área costera adyacente al sur de California, la biomasa fitoplanctónica y la producción orgánica primaria han sido medidas desde 1974 (Eppley y Holm-Hansen, 1986). Una meta de este trabajo fue desarrollar la información y comprensión de los ciclos biogeoquímicos en aguas superficiales. Los elementos carbono y nitrógeno han sido enfatizados hasta la fecha, en relación a la producción primaria nueva y regenerada. En este trabajo se pretende estudiar los resultados obtenidos de sílice biogénico particulado (PSi) que fue incluido en este programa recientemente con el objetivo de estimar la biomasa instantánea en términos de PSi y establecer su tasa de producción en la zona eufótica en relación con el nitrógeno y el carbono.

La producción fitoplanctónica y su destino en el océano son importantes para la comprensión de los ciclos biogeoquímicos de los elementos incluyendo el silicio (Berger, 1976; Broecker y Peng, 1982; Spencer, 1983). Las aguas profundas del Pacífico Nororiental tienen concentraciones de sílice disuelto muy altas con relación al océano mundial (Berger, 1976; Broeker y Peng, 1982); aunque sobre la nutriclina, se pueden detectar concentraciones

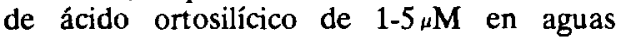
oligotróficas del área.

Las imágenes térmicas de satélite sobre la Corriente de California muestran que el agua fría (y rica en nutrientes) en las áreas de surgencias frente al norte y centro de California se extiende hacia el sur más allá de Punta Concepción y las islas del Canal mientras que las aguas cálidas (y pobres en nutrientes) se encuentran en el área adyacente al sur de California. Alli, toda vez que se detectan lenguas de agua rica, ellas aparecen en una franja de unos pocos kilómetros de distancia de la costa y con muy corta duración (Jackson, 1986). Las imágenes de satélite de clorofila y de pigmentos relacionados demuestran bajas concentraciones de clorofila en el área (Smith y Baker, 1982; Carlucci et al., 1986; Pelaez y McGowan, 1986). La variabilidad espacial y temporal de los nutrientes y de la producción primaria sugiere que condiciones oligotróficas son por ley general, las características del medio que reinan en esta zona 
10-12 May 1985 (SCBS-23), 8-13 October 1985 (SCBS-24), 2-8 April 1986 (SCBS-25), 4-9 September 1986 (SCBS-26), and 7-12 January 1987 (SCBS-27). Station locations are shown in Figure 1. Work on station consisted of a CTD-rosette system cast to $100 \mathrm{~m}$ or less, depending on water depth. The CTD-rosette system included a scalar irradiance quanta meter (Booth, 1976) used to define the depth of the euphotic zone (i.e. when submarine light was $1 \%$ of the surface value) and to select sampling depths. These were chosen on the down-cast to match the light transmission of neutral density screens of deck incubators used for bottle incubations. The rosette was fitted with 5 -liter Niskin sampling bottles. The bottles were fired on the up-cast. Additional casts were made with 30-liter Niskin bottles when larger samples were required.

\section{Analysis}

Water from the sampling bottles was passed through a 183 nitex screen to remove any of the larger zooplankton before analytical work commenced. Primary production measurements were made using $250 \mathrm{ml}$ polycarbonate bottles containing about $200 \mathrm{ml}$ seawater and about $148 \mathrm{kBq}{ }^{14} \mathrm{C}$ bicarbonate. These samples were incubated for 24 hours and were then filtered using $G F / F$ glass fiber filters. After rinsing with filtered seawater, the filters were placed in scintillation vials with cocktail and returned to the laboratory for radioassay. The latter used standard ${ }^{1}{ }^{4} \mathrm{C}$-toluene for calibration and external standards ratio for quench corrections.

Similarly, GF/F filters were used for chlorophyll and POC/PON filtrations. Filters for the latter were pre-combusted at $500^{\circ} \mathrm{C}$ to remove organic matter. Filters for chlorophyll analysis were homogenized in a teflon/glass tissue grinder in $90 \%$ acetone for extraction of pigments using 3-4 aliquots of acetone to assure complete extraction. The aliquots were made up to $10 \mathrm{ml}$ volume in centrifuge tubes and these were stored in a dark container at $-10^{\circ} \mathrm{C}$ for several hours. Finally, the samples were centrifuged and the acetone extracts transferred to cuvettes for determination of chlorophyll $a$ fluorescence, before and after acidification with $\mathrm{HCl}$. Calculations of chloro- con fuertes variaciones a escala estacional e interanual.

\section{MATERIALES Y METODOS}

\section{Muestreo}

Las muestras fueron tomadas en cinco cruceros realizados en la zona norte del área adyacente al sur de California en las fechas: 10-12 de mayo, 1985 (SCBS-23); 8-13 de octubre, 1985 (SCBS-24); $1-8$ de abril, 1986 (SCBS-25); 4-9 de septiembre, 1986 (SCBS-26) y 7-12 de enero, 1987 (SCBS-27). La localización de las estaciones se presenta en la Figura 1. El trabajo en la estación consistió en lanzar el CTD en un sistema de roseta a $100 \mathrm{~m}$ ó menos dependiendo de la profundidad del fondo. El sistema de roseta con CTD incluyó un "quanta-metro" de irradianza escalar (Booth, 1976) que fue utilizado para determinar la profundidad de la capa eufótica (i.e. cuando la luz submarina era el $1 \%$ del valor de superficie) y para determinar las profundidades de muestreo. Estas fueron escogidas sobre el lance según la transmisión de la luz calibrada con pantallas neutras instaladas en cubierta que eran utilizadas para la incubación en botellas. En la roseta se fijaron botellas Niskin de 5 litros. Las botellas hidrológicas fueron cerradas desde el puente. Cuando se necesitaba volúmenes mayores de muestra, se hacían lances adicionales usando botellas Niskin de 30 litros.

\section{Análisis}

El agua era prefiltrada a través de una red de $183 \mu \mathrm{m}$ de luz de malla para remover los organismos zooplanctónicos antes de que cualquier análisis se realizara. Las medidas de producción primaria fueron hechas antes de que el trabajo analítico comenzara. Las estimaciones de producción primaria fueron hechas utilizando botellas de policarbonato de $250 \mathrm{ml}$ de capacidad con cerca de $200 \mathrm{ml}$ de agua y bicarbonato marcado con ${ }^{14} \mathrm{C}$ (148 $\mathbf{k B q}$ ). Estas muestras fueron incubadas durante 24 horas y entonces fueron filtradas a través de filtros de fibra de vidrio $G F / F$. Después de enjuagar con agua de mar filtrada, los filtros fueron puestos en frasquitos con una solución comercial de centelleo y guardados para ser analizados en el laboratorio. Al final, 


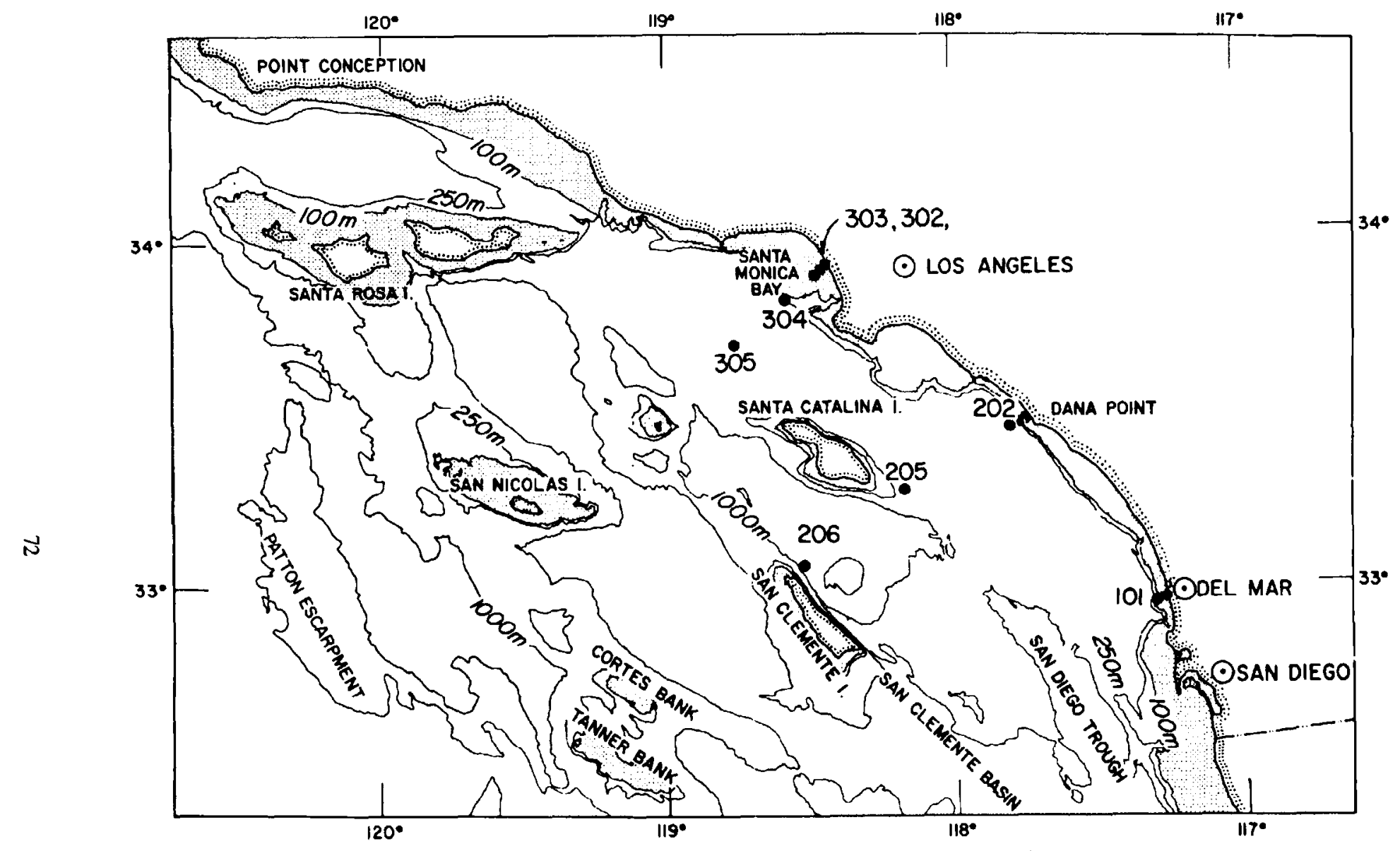

Figure 1. Station locations off southern California. Depth contours are drawn for 100, 250 and $1000 \mathrm{~m}$ depths. Stippled areas are $<100 \mathrm{~m}$ depth. The main flow of the California Current is southerly and west of Santa Rosa and San Nicolás Islands.

Figura 1. Localización de estaciones frente al sur de California. Los contornos de profundidades fueron dibujados para 100,250 y $1000 \mathrm{~m}$. Las áreas sombreadas corresponden a profundidades $<100 \mathrm{~m}$. El flujo principal de la Corriente de California es hacia el sur y oeste de las Islas Santa Rosa y San Nicolás. 
phyll $a$ and pheopigments followed Strickland and Parsons (1972).

POC/PON filters, containing the particulate matter from 1-4 liters of seawater, were stored frozen on the ship and were analyzed ashore using an HP-185B CHN analyzer (Sharp, 1974). Seawater samples were also filtered using GF/F filters for nutrient analysis. The filtered water samples were frozen on the ship and analyzed ashore for phosphate, nitrate and silicic acid using the methods in Strickland and Parsons (1972), scaled down for smaller sample sizes. Nitrate and nitrite were also measured on the ship using chemiluminescent methods (Garside, 1982). Phytoplankton carotenoids were determined for samples collected on cruise SCBS-23 by high-performance liquid chromatography using the method of Mantoura and Llewellyn (1983) with some modifications (described in Nelson, 1986). The pigment samples $(n=18)$ were collected on separate rosette casts.

\section{Particulate silicon}

The method used for the determination of silica content in the natural particulates is an application of that described by Paasche (1980). Seawater samples, $250-550 \mathrm{ml}$, were filtered with $0.6 \mu \mathrm{m}$ pore size Nucleopore filters. The filters were placed in $50 \mathrm{ml}$ polypropylene centrifuge tubes and kept frozen until analyzed. The particulate material was heated in a dilute sodium carbonate solution, $18 \mathrm{ml}$ of $0.5 \%$ solution kept at $85^{\circ} \mathrm{C}$ for two hours. Samples were then cooled, neutralized with $0.5 \mathrm{~N} \mathrm{HCl}$ to methyl orange end point, and made up to $25 \mathrm{ml}$ volume. Five $\mathrm{ml}$ aliquots were used for determination of silicic acid following Strickland and Parsons (1972). The PSi method is quite specific for biogenic silica because of the hydrolysis in dilute sodium carbonate solution (Paasche, 1980; Krause et al., 1983).

A crude estimate of the production rate of biogenic silica was calculated as the product of the $\mathrm{PSi} / \mathrm{POC}$ ratio and the rate of primary production of carbon. This rate will be called the "expected rate" of opal production. el estándar usado para la calibración fue ${ }^{14} \mathrm{C}$-tolueno y se hicieron las correcciones de efecto de amortiguación con la razón de estándares externos.

De manera similar, para las filtraciones de fitoplancton con el fin de determinar la concentración de clorofilas y POC/PON se utilizaron filtros GF/F. Para este último, los filtros fueron previamente incinerados a $500^{\circ} \mathrm{C}$ para eliminar la materia orgánica. Los filtros para análisis de clorofila fueron triturados en un molinillo de émbolo de vidrio-teflón en acetona al $90 \%$ para la extracción de pigmentos utilizando 3-4 alícuotas de acetona para asegurar la extracción completa. Las alícuotas se llevaron a un volumen de $10 \mathrm{ml}$ en tubos de centrífuga que fueron guardadas en una caja obscura a $-10^{\circ} \mathrm{C}$ durante varias horas. Finalmente, las muestras fueron centrifugadas y los extractos en acetona fueron transferidos a cubetas para determinación de clorofila $a$ por fluorescencia, antes y después de acidificación con $\mathrm{HCl}$, en el barco. Las concentraciones de clorofila $a$ y de feopigmentosfueron calculadas siguiendo a Strickland y Parsons (1972).

Los filtros para determinaciones de POC/PON conteniendo el material particulado de 1-4 litros de agua de mar fueron guardados en el barco y posteriormente fueron analizados en tierra en un analizador CHN 185B (Sharp, 1974). Las muestras para el análisis de nutrientes también fueron filtradas a través de filtros GF/F. Las muestras de agua filtrada para análisis de fosfatos, nitratos, nitritos y ácido silícico fueron congeladas en el barco y analizadas en tierra siguiendo el método colorimétrico, para muestras pequeñas descrito en Strickland y Parsons (1972). Los nitratos y nitritos tambien fueron analizados en el barco usando los métodos de quimioluminiscencia (Garside, 1982). Los carotenoides del fitoplancton fueron determinados únicamente en muestras recolectadas durante el crucero SCBS-23, por cromatografia en fase líquida de alta resolución usando el método de Mantoura y Llewellyn (1983) con algunas modificaciones descritas en Nelson (1986). Estas muestras para pigmentos $(n=18)$ fueron recolectadas en lances separados del sistema de roseta. 


\section{RESULTS}

Ambient concentrations of dissolved silicic acid

Concentrations of silicic acid increase with depth in the ocean as do other biogenic elements (Broecker and Peng, 1982). Surface waters of the Southern California Bight are often depleted of these nutrients with nitrate $<100 \mathrm{nM}$, phosphate equal or more than $100 \mathrm{nM}$ and silicic acid somewhat higher: 1-3 $\mu \mathrm{M}$. Concentrations of all three nutrients increase with depth within the euphotic zone in this region, although sometimes only near the $1 \%$ light depth. Concentrations of these nutrients are highly correlated within the nutricline.

Use of the chemoluminescent nitrate analyzer (Garside, 1982) allowed us to examine the relation between silicic acid and nitrate concentrations in the $\mathrm{N}$-depleted waters above the nutricline. Linear regression of silicic acid concentration on nitrate concentration, done separately for the four cruises with samples above the nutricline, showed significant correlation for only one (SCBS-26) of the four. The silicic acid intercept at zero nitrate varied from 0.75 to $2.8 \mu \mathrm{M}$. Nitrate concentrations were in the range $10-80 \mathrm{nM}$. On three occasions (twice at station 202, once at station 302) nitrate was elevated (about $500 \mathrm{nM}$ ) without a corresponding increase in silicic acid. Nitrate and silicic acid concentrations were clearly independent above the nutricline at these nearshore stations.

\section{Spatial distribution of PSi}

The concentration of PSi decreased offshore as did other measures of particulate matter in the euphotic zone (Table I). This horizontal onshore-offshore gradient is a recurring feature of biogenic particle concentrations (reviewed by Mullin, 1986) including PSi in the present study.

Depth distributions of PSi were variable and showed no trend with depth in the euphotic zone (Table I). An example of a depth profile with a PSi peak in the chlorophyll maximum is shown in Figure 2. Also shown for comparison are the depth profiles of chlorophyll, dissolved nitrate and silicic acid,

\section{Silicio particulado}

El método utilizado para determinar el contenido silícico en las partículas naturales es una modificación del descrito por Paasche (1980). Las muestras de agua de $250-500 \mathrm{ml}$, fueron filtradas sobre filtros Nucleopore con poro de diámetro $0.6 \mu \mathrm{m}$. Los filtros fueron almacenados en botellas de propileno de $50 \mathrm{ml}$ de capacidad y congelados hasta su análisis. El material particulado fue calentado a baño María a $85^{\circ} \mathrm{C}$ sumergido en $18 \mathrm{ml}$ de una solución al $0.5 \%$ de carbonato de sodio, durante dos horas. Las muestras, entonces fueron enfriadas, neutralizando hasta punto final de naranja de metilo con $\mathrm{HCl}$ al $0.5 \mathrm{~N}$ y se aforaron a $25 \mathrm{ml}$. Las determinaciones de concentración de ácido silícico se realizaron en alícuotas de $5 \mathrm{ml}$ siguiendo el método de Strickland y Parsons (1972). El.método de PSi es específico para el silicio biogénico debido a la hidrólisis en solución de carbonato de sodio diluido (Paasche, 1980; Krause et al., 1983).

La tasa de producción de sílice biogénico se calculó como el producto de la razón PSi/POC y la tasa de producción primaria de carbono. Esta tasa ha sido denominada "tasa esperada" de producción de ópalo.

\section{RESULTADOS}

\section{Ślice disuelto en el medio}

La concentración de ácido silícico aumenta con la profundidad en el océano de la misma manera que lo hacen otros nutrientes del fitoplancton (Figs. 2 y 3). Las aguas de superficie de la región adyacente al sur de California son a menudo muy bajas en estos nutrientes con concentraciones de nitratos menores de $100 \mathrm{nM}$, fosfatos mayores o igual a $100 \mathrm{nM}$ y el ácido ortosilícico algo mayor que 1-3 $\mu \mathrm{M}$. La concentración de los tres nutrientes aumenta con la profundidad dentro de la zona eufótica en esta región, aunque a veces sólo cerca de la profundidad de $1 \%$ de luz. Las concentraciones de estos nutrientes se encuentran fuertemente correlacionadas dentro de la nutriclina (Broecker y Peng, 1982).

El uso del analizador de nitratos de quimioluminiscencia (Garside, 1982) permitió examinar la relación entre las concentraciones 


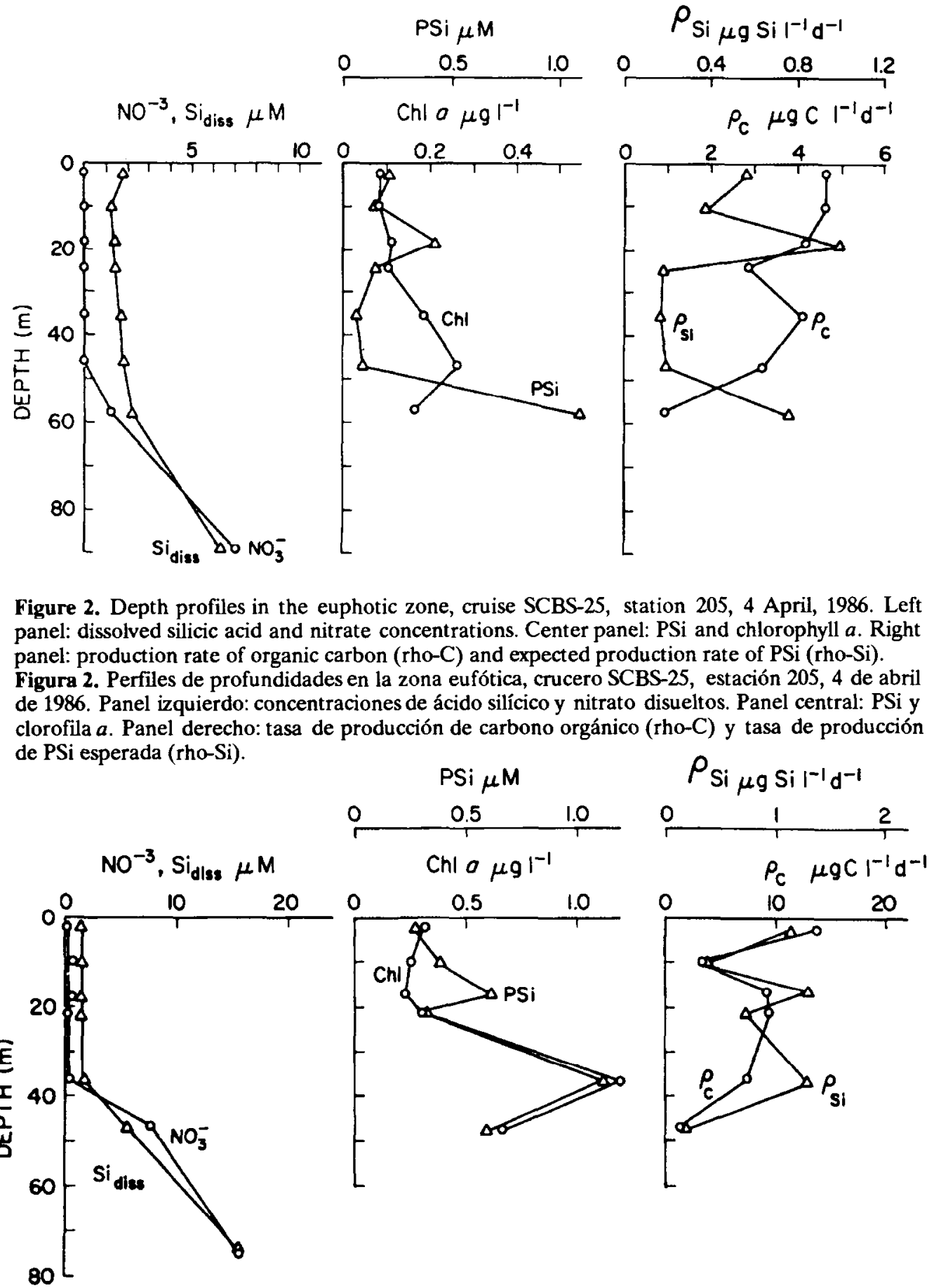

Figure 3. Depth profile at sation 205, cruise SCBS-27, 8 January, 1987. Panel descriptions as in Figure 2.

Figura 3. Perfiles de profundidades en la estación 205, crucero SCBS-27, 8 de enero de 1987. Descripción de panel en la Figura 2. 
primary production, and the expected production rate of $\mathrm{PSi}$. A chlorophyll maximum typically rests upon the nutricline, as in Figure 2 (Cullen and Eppley, 1981). Primary production was highest above the chlorophyll maximum and that is also typical.

Another depth profile with bimodal PSi is shown in Figure 3, a case of maximum PSi at the base of the euphotic zone. The nutricline was deep in this profile, chlorophyll concentrations were low and the chlorophyll maximum was quite small. Primary production was only $205 \mathrm{mg} \mathrm{C} \mathrm{m}^{-2} \mathrm{~d}^{-1}$, about half of the long-term mean for the Bight (Eppley and Holm-Hansen, 1986).

\section{PSi relations to other variables}

Mean values of the ratio of PSi to POC, PON and chlorophyll $a$ are given in Table II. Except in occasional blooms (Eppley et al., 1977) when phytoplankton carbon dominates the POC, about one-third of the POC consists of phytoplankton carbon, another third is bacterial carbon (B. Cho and F. Azam, personal communication) and the remaining third consists of other small heterotrophs and organic detritus. In the present series of 27 SCBS cruises since 1974, a diatom bloom (chlorophyll $a$ about $5 \mu \mathrm{g} /$ liter) was encountered only once, and only at a single station near station 101. Dinoflagellate blooms, with chlorophyll a 5-10 $\mu \mathrm{g} / \mathrm{liter}$ have been noted more frequently near stations 302 and 202 . Diatom blooms are not a common feature of the Southern California Bight, a conclusion consistent with the present observations of PSi concentrations.

PSi was correlated with POC, PON, chlorophyll and other materials on one or more cruises in the Bight (Table III). Particulate aluminum, and hence alumino-silicates, were found only at low concentrations in the area (Sackett and Arrhenius, 1962). That observation, plus the selectivity of the analytical method for biogenic silica makes the correlation of PSi with biogenic particulate indicators an expected result. The correlations, however, were not uniform between cruises (Table III). Such variability probably arises from changes in the taxonomic composition of the plankton and the varying impor- de nitrato en las aguas casi desprovistas que se encuentran sobre la nutriclina y la concentración de ácido silícico. Al estudiar la regresión linear entre la concentración de ácido silícico y de nitratos con muestras tomadas sobre la nutriclina y calculadas separadamente para cada crucero, se encontró solo correlación significativa en uno (SCBS-26) de cuatro. La intercepción de la recta de correlación de la concentración de ácido silícico con el cero de nitratos varió de 0.75 a $2.8 \mu \mathrm{M}$. Las concentraciones de nitratos variaron entre $10 \mathrm{y}$ $80 \mathrm{nM}$. En tres ocasiones (dos veces en la estación 202, una en la estación 302) el nitrato fue alto (cerca de $500 \mathrm{nM}$ ) sin correspondencia con un aumento de ácido silícico. Las concentraciones de nitratos y silicatos fueron claramente independientes sobre la nutriclina en estas estaciones cercanas a la costa.

\section{Distribución espacial de PSi}

La concentración de PSi disminuye hacia mar adentro, al alejarse de la costa, así como las otras medidas de material particulado (Tabla I). Este gradiente horizontal al alejarse de la costa es un aspecto recurrente de las concentraciones de partículas biogénicas (revisado por Mullin, 1986) a lo que se agrega el PSi con el presente estudio.

La distribución de PSi fue variable y no demostró ninguna tendencia en la capa eufótica (Tabla I). Un ejemplo de perfil con un aumento de PSi en la profundidad de máximo de clorofila es mostrado en Figura 2. Alli también a manera de comparación se presentan los perfiles de clorofila, nitrato disuelto y ácido silícico, producción primaria y tasa esperada de producción de PSi. En la Figura 2, un máximo de clorofila está típicamentc sobre la nutriclina (Cullen y Eppley, 1981). La producción primaria más alta ocurrió a una profundidad más somera que la de máxima clorofila, lo que también es típico en esta área.

Otro perfil con una curva de PSi bimodal es mostrado en la Figura 3; en este caso el valor máximo de PSi se encontró en la base de la zona eufótica. En este perfil, la nutriclina fue profunda, las concentraciones de clorofila fueron bajas y el nivel de máxima clorofila fue levemente superior. La producción primaria fue solamente de $205 \mathrm{mg} \mathrm{C} \mathrm{m}^{-2} \mathrm{~d}^{-1}$, lo que 
Table I. Variation in particulate biogenic silica with distance offshore, with light depth, and between cruises. Results of variance analysis using the Kruskal-Wallis $\mathbf{H}$ test for nonparametric data. The null hypothesis is "the samples do not differ".

Tabla I. Variación del sílice biogénico particulado con la distancia a la costa, profundidad de penetración de la luz y entre cruceros. Resultados del análisis de varianza usando la prueba estadística de Kruskal-Wallis. La hipótesis nula es "las muestras no difieren entre sí".

\begin{tabular}{lrcrll}
\hline & $\mathrm{H}$ & $X^{2}$ & d.f. & & \\
\hline Distance offshore & 30.24 & 0.000035 & 6 & $<.001$ & $\mathrm{H}_{\mathrm{O}}$ is rejected \\
Light depths & 13.73 & 0.248025 & 11 & $>.100$ & $\mathrm{H}_{\mathrm{O}}$ is accepted \\
Cruises & 15.34 & 0.004041 & 4 & $<.010$ & $\mathrm{H}_{\mathrm{O}}$ is rejected \\
\hline
\end{tabular}

Table II. Ratios of particulate Si to particulate carbon (POC), particulate nitrogen (PON), chlorophyll $a(\mathrm{Chl})$, and fucoxanthin $(\mathrm{Fx})$. Ratios are by moles for POC, PON and moles $\mathrm{PSi} /$ gram pigment for chlorophyll $a$ and fucoxanthin. Mean values for all the data are $0.356 \mu \mathrm{M}$ POC, $1.18 \mu \mathrm{M}$ PON, $0.546 \mu \mathrm{g} / 1$ chlorophyll $a$ and $0.289 \mu \mathrm{g} / 1$ fucoxanthin. There are 102 samples for PSi, POC, PON and chlorophyll $a$, and 18 of these include fucoxanthin. Fourteen samples were from distinct sub-surface chlorophyll maxima.

Tabla II. Razones de sílice particulado con respecto a carbono particulado (POC), nitrógeno particulado (PON), clorofila $a(\mathrm{Chl})$ y ficoxantina (Fx). Las razones están en número de moles de PSi por POC, PON y moles de PSi por $\mathrm{g}$ de pigmentos por clorofila $a$ y ficoxantina. Los valores promedio de todos los datos son $0.356 \mu \mathrm{M}$ POC, $1.18 \mu \mathrm{M}$ PON, $0.546 \mu \mathrm{g} / 1$ de clorofila $a \mathrm{y}$ $0.289 \mu \mathrm{g} / 1$ ficoxantina. De 102 muestras para PSi, POC, PON y clorofila $a, 18$ incluyen ficoxantina. Para la profundidad del máximo de clorofila se diferenciaron 14 muestras.

\begin{tabular}{lccccc}
\hline \multicolumn{5}{c}{ All Samples } \\
& PSi/POC & PSi/PON & PSi/Chl & PSi/Fx & Chl/Fx \\
\hline $\bar{X}$ & 0.047 & 0.317 & 0.852 & 3.61 & 4.24 \\
s.d. & 0.033 & 0.214 & 0.693 & 3.12 & 4.50 \\
\hline
\end{tabular}

Chlorophyll Maximum Samples

\begin{tabular}{llllll}
\hline $\bar{X}$ & 0.047 & 0.296 & 0.450 & - & - \\
s.d. & 0.24 & 0.112 & 0.201 & - & - \\
\hline
\end{tabular}


Table III. Spearman rank correlation coefficients between particulate silica and other measures of particulate matter, dissolved silicic acid and nitrate concentrations, and rate of primary production. Results are separate for each cruise. Correlation coefficients are given separately for samples from the chlorophyll maximum depths for all the cruises together. $N=$ number of samples.

Tabla III. Coeficiente de correlación de Spearman entre sílice particulado y otras medidas de material orgánico, ácido silícico disuelto, concentración de nitratos y tasa de producción primaria. Los resultados están separados por cada crucero. Los coeficientes de correlación para muestras de la profundidad de máxima clorofila en conjunto son proporcionados separadamente. $\mathrm{N}$ = número de muestras.

\begin{tabular}{llllllllll}
\hline & & \multicolumn{7}{c}{ Rank Correlation Coefficient, PSi versus: } \\
& & & PON & Chl $a$ & Si & Nitrate & Primary & N \\
& & & & & diss. & & Prod. & \\
\hline SCBS-24 & Oct. 1985 & $0.64^{* *}$ & $0.70^{* *}$ & $0.49^{*}$ & 0.30 & 0.26 & 0.10 & 18 \\
SCBS-25 & Apr. 1986 & 0.16 & 0.10 & $0.47^{* *}$ & 0.05 & $0.47^{* *}$ & $-0.38^{*}$ & 26 \\
SCBS-26 & Sep. 1986 & $0.42^{*}$ & $0.40^{*}$ & $0.46^{*}$ & -0.21 & -0.17 & $0.44^{*}$ & 18 \\
SCBS-27 & Jan. 1987 & $0.67^{* *}$ & $0.67^{* *}$ & $0.43^{* *}$ & -0.10 & 0.21 & $0.66^{* *}$ & 38 \\
Chlrophyll max. depth & $0.80^{* *}$ & $0.93^{* *}$ & $0.80^{* *}$ & -0.32 & -0.10 & $0.70^{* *}$ & 14 \\
\hline
\end{tabular}

$\mathrm{p}<0.05$

** $\mathrm{p}<0.01$

Table IV. Depth integrated values for "expected rates" of opal production ( $\mathrm{m}$ mole Si $\mathrm{m}^{-2} \mathrm{~d}^{-1}$ ), organic carbon production $\left(\mathrm{m}\right.$ moles $\left.\mathrm{C}^{-2} \mathrm{~d}^{-1}\right)$, PSi $\left(\mathrm{m}\right.$ mole $\left.\mathrm{m}^{-2}\right)$ and POC $\left(\mathrm{m} \mathrm{mole} \mathrm{m}^{-2}\right) .4-7$ depths were sampled in each profile.

Tabla IV. Valores para "tasa esperada" de producción de ópalo (m moles Si $\mathrm{m}^{-2} \mathrm{~d}^{-1}$ ), producción de carbón orgánico (m moles $\left.\mathrm{C} \mathrm{m}^{-2} \mathrm{~d}^{-1}\right)$, PSi (m moles $\left.\mathrm{m}^{-2}\right)$ y POC $\left(m\right.$ moles $\mathrm{m}^{-2}$ ). En cada perfil se tomaron muestras de 4-7 profundidades.

\begin{tabular}{|c|c|c|c|c|c|}
\hline \multirow[b]{2}{*}{ Cruise } & \multicolumn{3}{|c|}{ Standing Stock } & \multicolumn{2}{|c|}{ Production Rate } \\
\hline & Sta & PSi & POC & PSi & POC \\
\hline \multirow[t]{3}{*}{ SCBS-25 } & 202 & 22.3 & 397 & 4.23 & 97.5 \\
\hline & 205 & 27.8 & 501 & 1.43 & 29.1 \\
\hline & 206 & 18.6 & 469 & 2.00 & 59.7 \\
\hline \multirow[t]{6}{*}{ SCBS-27 } & 202 & 16.6 & 233 & 4.25 & 58.4 \\
\hline & 205 & 14.2 & 214 & 0.84 & 16.9 \\
\hline & 302 & 14.3 & 239 & 3.95 & 63.3 \\
\hline & 303 & 8.45 & 213 & 1.34 & 23.0 \\
\hline & 304 & 7.68 & 224 & 0.87 & 23.1 \\
\hline & 305 & 6.14 & 185 & 0.79 & 22.6 \\
\hline
\end{tabular}


tance of diatoms, silicoflagellates and radiolarians. Species enumerations were beyond the scope of this study.

The highest correlations were between PSi and other particulates at the depth of the chlorophyll maximum (Table III). For example, Figure 4 shows PSi vs. chlorophyll $a$ at the chlorophyll maximum depth.

Since the chloroplast pigment fucoxanthin is not only found in diatoms and silicoflagellates but also in non-siliceous chrysophytes, we expected its distribution to be similar to that of PSi. The two were not highly correlated, however (Fig. 5). In fact, fucoxanthin was only a slightly better estimator of PSi than chlorophyll $a$. Spearman rank correlation coefficients were 0.58 and 0.45 for PSi vs. fucoxanthin or chlorophyll $a$, respectively. (The correlation between PSi and chlorophyll was higher than this in the subsurface chlorophyll maximum, see Table III. Unfortunately there was only one fucoxanthin analysis from the chlorophyll maximum.)

\section{Expected rate of opal production}

Examples of the depth variation in expected opal production ( $(\mathrm{Si}$ ) (Figs. 2 and 3 ) suggest abrupt changes with depth. The primary production profiles were fairly smooth; the spikes in $\mathrm{PSi}$ in these examples were due primarily to the PSi distributions. Other pSi profiles were smoother, with highest $\rho \mathrm{Si}$ at the surface or mid-depth, declining at the base of the euphotic zone.

Depth integrated $\rho$ Si was calculated for stations with data for at least four depths in the euphotic zone (Table IV). Rates were highest at the inshore stations. The residence time of silicic acid above the nutricline was calculated as (ambient concentration)/(expected opal production rate). Residence times at inshore stations were 1-2 weeks, at offshore stations 2-10 weeks. These residence times are long relative to those for inorganic nitrogen.

\section{DISCUSSION AND CONCLUSION}

\section{Distribution of particulate Si}

The aspects of PSi distribution examined here were limited to depth variations, the corresponde a cerca de la mitad del promedio a largo plazo reportado para esta área por Eppley y Holm-Hansen (1986).

\section{Relaciones de PSi con otras variables}

Valores promedio de la razón PSi con POC, PON y clorofila $a$ son presentados en la Tabla II. A excepción de florecimientos ocasionales de fitoplancton (Eppley et al., 1977), cuando el carbono fitoplanctónico domina el POC, cerca de un tercio del POC proviene del fitoplancton, otro tercio es carbono bacteriano (B. Cho y F. Azam, comunicación personal) y el tercio que queda corresponde a otros heterótrofos pequeños y detritus orgánico. En la serie del crucero SCBS-27, un florecimiento de diatomeas (clorofila $a$ cerca de $5 \mu \mathrm{g} /$ litro) fue encontrado solo una vez y solamente en una estación cerca de la estación 101. Florecimientos de dinoflagelados, con 5-10 $\mu \mathrm{g} /$ litro de clorofila $a$ fueron encontrados más frecuentemente cerca de las estaciónes 302 y 202. Los florecimientos de diatomeas en general no son muy comunes en la región adyacente al sur de California, lo que es coherente con las concentraciones de PSi que resultaron en este trabajo.

El PSi se correlacionó con el POC, PON, clorofila y otros materiales en uno o más cruceros en el área (Tabla III). El aluminio particulado y consecuentemente los silicatos aluminados se encuentran solamente en bajas concentraciones en el área (Sackett y Arrhenius, 1962). Esa observación más la selectividad del método empleado para el sílice biogénico, hacen que la correlación del PSi con otros indicadores de partículas biogénicas fueran resultados esperados. Las correlaciones sin embargo, no fueron uniformes entre cruceros (Tabla III). Tal variabilidad probablemente provenga de cambios en la composición taxonómica del plancton y de la variación de importancia entre diatomeas, silicoflageladas y radiolarios.

Las correlaciones más altas que se encontraron entre el PSi y otras partículas ocurrieron en la profundidad de clorofila máxima (Tabla III). Por ejemplo la Figura 4 muestra PSi vs. clorofila $a$ en la profundidad de máxima clorofila. 


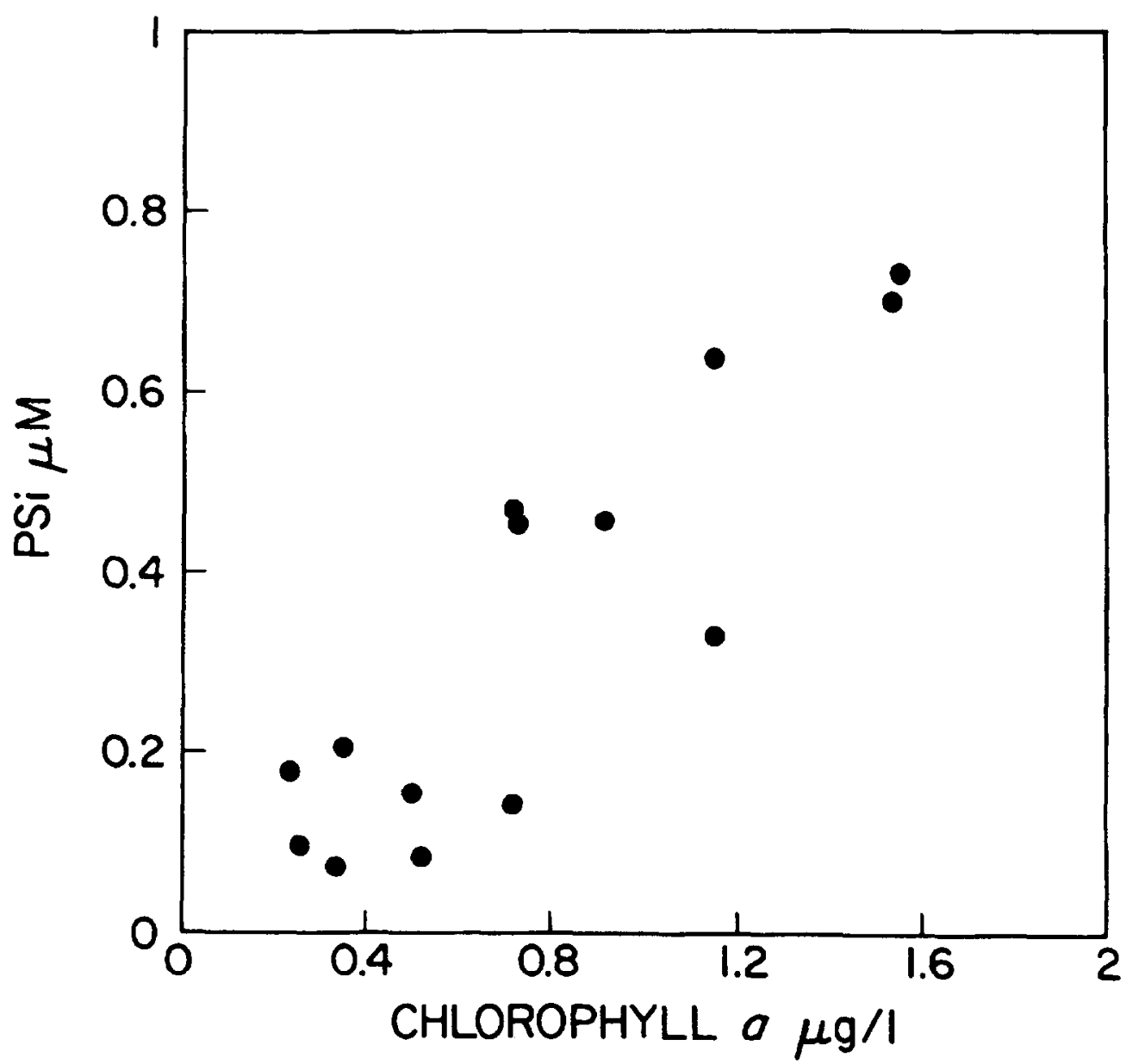

Figure 4. PSi vs, chlorophyll $a$ concentration in samples from the subsurface chlorophyll maximum. A linear regression line among the points is $\mathrm{PSi}=-0.20+0.47(\mathrm{Chl}), \mathrm{r}=0.88, \mathrm{p}<0.01$, $\mathbf{N}=14$.

Figura 4. PSi vs. concentración de clorofila $a$ en muestras del máximo subsuperficial de clorofila. La regresión lineal a través de los puntos es $\mathrm{PSi}=-0.20+0.47(\mathrm{Chl}), \mathrm{r}=0.88, \mathrm{p}<0.01, \mathrm{~N}=14$.

onshore-offshore gradient, and differences between cruises in the period 1985-87. The onshore-offshore gradient was expected from previous studies of the distribution of biogenic particulate matter. Likewise, between cruise variability is to be expected as the waters of the Southern California Bight are sometimes oligotrophic and at other times moderately productive. Information on temporal and spatial variability has been summarized recently by Mullin (1986) and Eppley and Holm-Hansen (1986). The lack of any consis-
Aunque la ficoxantina de los cloroplastos no solo se encuentra en diatomeas y silicoflageladas sino también en chrysophyta no silícica, se esperó que su distribución fuera similar a aquella de PSi. Las dos sin embargo, no se correlacionaron fuertemente (Fig. 5). En efecto, ficoxantina fue sólo un levemente mejor estimador de PSi que clorofila $a$. Los coeficientes de rango de Spearman fueron 0.58 y 0.45 para PSi vs. ficoxantina y clorofila $a$, respectivamente. (La correlación entre PSi y clorofila fue mayor que ésta en el nivel de 


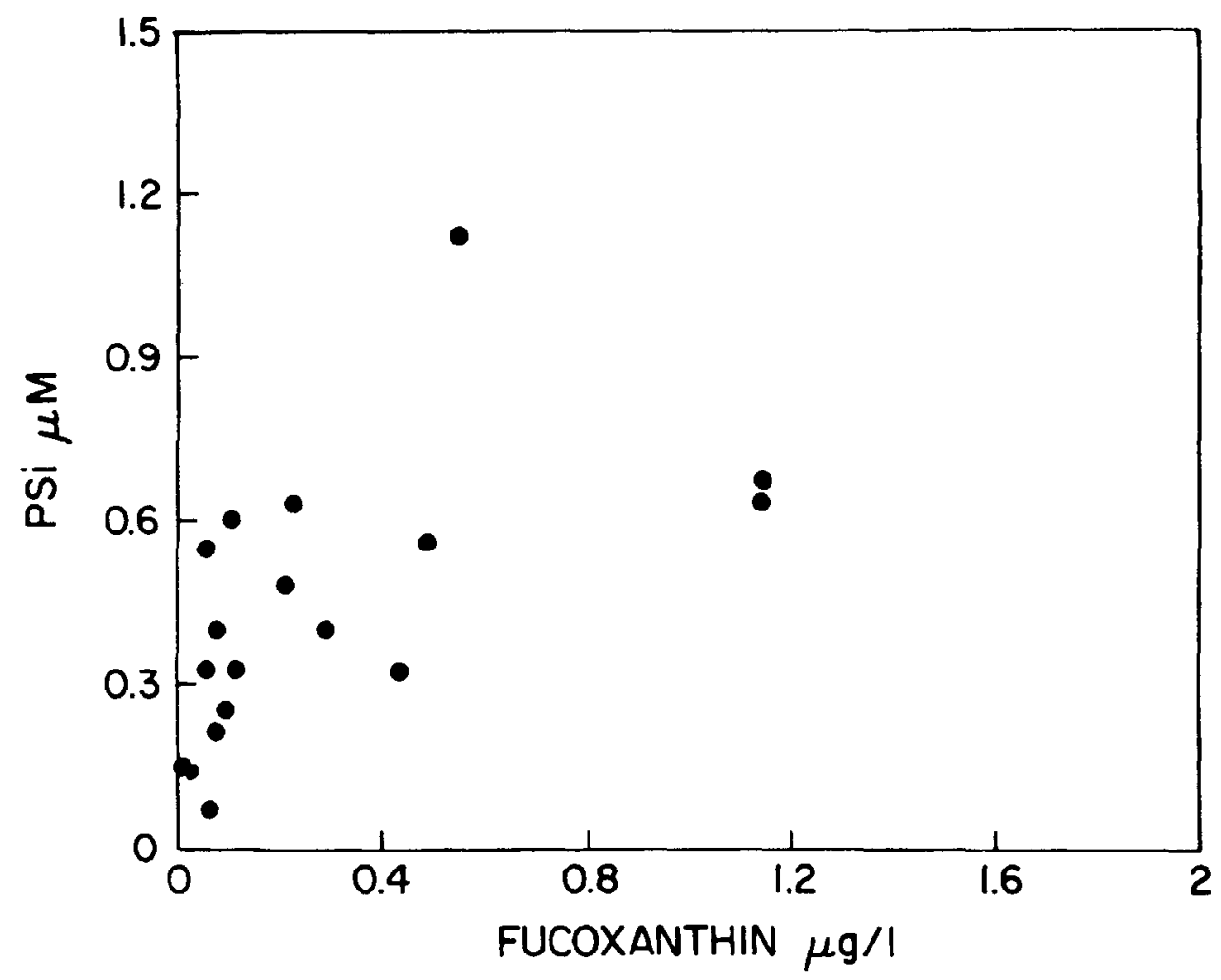

Figure 5. PSi vs. fucoxanthin concentration for cruise SCBS-23.

Figura 5. PSi vs. concentración de ficoxantina para el crucero SCBS-23.

tent relation of PSi to light depth was a little surprising as there was evidence from an earlier study that certain large-celled diatoms might be dependent upon nitrate concentration (Eppley, 1970). More recent work on phytoplankton species distributions have shown diatoms in both surface and chlorophyll maximum assemblages (Cullen et al., 1982 and references therein), but not in bloom proportions. The historical record of diatoms sampled at Scripps Institution of Oceanography pier, 1920-1939, shows abundance inversely correlated with sea-surface temperature anomalies (Tont, 1987). It is tempting to associate them with near-shore cold water plumes discussed by Jackson (1986). Estimates of diatom biomass as POC or PSi have not been developed from these records so we cannot interpret them in the present context. Nowadays, we find the nanoplankton predominant in the Bight, with $50 \%$ or so of the chlorophyll passing a 5- $\mu \mathrm{m}$ screen Mullin, clorofila máxima subsuperficial, ver Tabla III. Desafortunadamente sólo hay un valor de ficoxantina del nivel de clorofila máxima.)

\section{Tasa esperada de producción de ópalo}

De las Figuras 2 y 3 como ejemplos de la variación con la profundidad de la tasa de producción de ópalo ( $(\mathrm{Si})$ (Figs. 2 y 3 ), se sugieren cambios abruptos con la profundidad. Los perfiles de producción primaria fueron regularmente suaves; los valores más altos en ${ }{ }_{\mathrm{Si}}$ en estos ejemplos se debieron principalmente a las distribuciones de PSi. Otros perfiles de $\rho \mathrm{Si}$ fueron más nuevos, con el $\rho \mathrm{Si}$ más alto en la superficie o a profundidad media, declinando hacia la base de la zona eufótica.

Los datos de $\odot \mathrm{Si}$ calculados integrando la profundidad para las estaciones con un mínimo de cuatro datos por perfil, se presen- 
1986). It is not clear whether species abundance has changed since $1920-1939$ or whether the earlier emphasis on diatoms simply reflected lack of information on nano- and phytoplankton.

PSi vs. other components of particulate matter

PSi concentrations were correlated with POC, PON, chlorophyll, and primary production (Table III), but not with dissolved silicic acid concentration. This suggests that the abundance of diatoms, silicoflagellates and other silicious plankton may vary with other measures of plankton standing stock independent of ambient silicic acid concentration. The correlations were not consistent between cruises (Table III) and were highest for the subsurface chlorophyll maximum depth zone.

The ratio of $\mathrm{PSi} / \mathrm{POC}$ has been reported in previous field studies (Table $\mathrm{V}$ ). The most extensive works are those of Copin-Montegut and Copin-Montegut (1978) for various regions of the world ocean, studies of plankton blooms in Oslofjord (Paasche and Ostergren, 1980), and ice-edge diatom blooms in the Antarctic (Wilson et al., 1986; Smith and Nelson, 1985). As in diatom cultures, the ratio of PSi/POC in diatom blooms can be 0.3 or more by moles (Table V). The ratio is lower in the oligotrophic waters reported by Lisitzin (1967), Copin-Montegut and Copin-Montegut (1978) and the present study (Table V). The overall mean value of 0.047 found here is within the range observed in other oligotrophic waters and is the same mean value found in surface waters of the Barents Sea by Rey and Skjoldal (1987). Phytoplankton comprises a higher proportion of the particulate matter in the chlorophyll maximum layer than in the upper euphotic zone in the Bight (Eppley et al., 1977). This may explain the higher correlation of PSi with POC, PON, chlorophyll $a$ and primary production found in the chlorophyll maximum (Table III). Mean ratios of PSi to PON, and chlorophyll $a$, but not for $P O C$, in the chlorophyll maximum were also higher than for all the samples taken together (Table II).

The ratio phytoplankton chlorophyll/carbon in the Bight is $0.014-0.020$ by weight in the upper waters and 0.025-0.050 in tan en la Tabla IV, donde se puede apreciar que los valores más altos aparecen en las estaciones más costeras.

\section{DISCUSION Y CONCLUSION}

\section{Distribución de Si particulado}

Los aspectos de distribuciones de PSi examinados aquí, fueron limitados a variaciones de profundidad, distancia de tierra a océano y diferencias entre cruceros en el período 1985-87. El gradiente de tierra a mar se esperaba de los resultados de estudios previos de la distribución de material particulado biogénico. Asimismo, la variabilidad entre cruceros era esperada debido a la oligotrofia que presenta algunas veces la región adyacente al sur de California, a diferencia de otros episodios moderadamente productivos o de evidente surgencia. La información sobre la variabilidad temporal fue resumida recientemente por Mullin (1986) y Eppley y Holm-Hansen (1986). La falta de una relación consistente entre PSi y la profundidad de la luz fue un poco sorprendente ya que existía evidencia de estudios precedentes que ciertas diatomeas de células grandes debían depender de la concentración de nitratos (Eppley, 1970). Trabajos más recientes sobre la distribución de especies del fitoplancton han demostrado la presencia de diatomeas en ambas colecciones sobre y en el máximo de clorofila (Cullen et al., 1982; y otras referencias en este trabajo), pero no en proporciones de florecimiento.

El registro histórico de las diatomeas recolectadas en el embarcadero de la Institución Scripps de Oceanografia, 1920-1939, ha demostrado correlación inversa con la anomalía térmica en superficie (Tont, 1987). Es tentador asociar la mayor abundancia de diatomeas con lenguas de agua fría discutidas por Jackson (1986). A partir de aquellos registros nunca se desarrollaron estimaciones de biomasa de diatomeas tales como POC o PSi, de manera que no se pueden interpretar en este contexto. En esta región predomina el nanoplancton con un $\mathbf{5 0 \%}$ o más de la clorofila que pasa a través de un filtro de $5 \mu \mathrm{m}$ de diámetro de poro (Mullin, 1986). No está claro si la abundancia de especies ha cambiado desde 1920-1939 o si los primeros trabajos que enfatizaron a las diatomeas, simplemente re- 
Table V. Ratio of particulate $S i$ to particulate carbon in various ocean regions.

Tabla V. Razón sillice particulado a carbono particulado en varias regiones del océano.

\begin{tabular}{|c|c|c|c|}
\hline Population & Conditions & $\begin{array}{l}\text { PSi/POC } \\
\text { (by atoms) }\end{array}$ & Reference \\
\hline \multirow{3}{*}{$\begin{array}{l}\text { Mixed populations of } \\
\text { coastal phytoplankton } \\
\text { (mainly diatoms) }\end{array}$} & $\begin{array}{l}\text { Growth of the phytoplankton bloom } \\
\text { species in a transparent plastic sphere }\end{array}$ & $\begin{array}{l}0.15-0.41 \\
0.20-0.39\end{array}$ & $\begin{array}{l}\text { McAlister et al.., } 1961 \\
\text { Antia et al., } 1963\end{array}$ \\
\hline & $\begin{array}{l}\text { Populations grown with excess } \mathrm{N}-\mathrm{NO}_{3} \\
\text { in the water }\end{array}$ & 0.60 & \\
\hline & Unheal thy crop in $\mathrm{N}-\mathrm{NO}_{3}$ depleted water & 0.43 & \\
\hline Natural populations & Not limiting growth & 0.34 & strickland, 1965 \\
\hline \multirow[t]{2}{*}{ Natural particulate matter } & Oligotrophic subtropical Indian Ocean & $0.008-0.018$ & Lisitzin, 1967 \\
\hline & Antarctic & 0.37 & \\
\hline \multirow[t]{4}{*}{ Natural populations } & Tropical and subtropical zone & $0.010-0.060$ & $\begin{array}{l}\text { Copin-Montegut and } \\
\text { Copin-Montegut, } 1978\end{array}$ \\
\hline & Subantarctic zone & $0.009-0.014$ & \\
\hline & Polar front & $0.026-0.35$ & \\
\hline & Antarctic zone & $0.020-0.40$ & \\
\hline \multirow[t]{2}{*}{ Natural populations } & $\begin{array}{l}\text { Uppermost layer of the inner oslof jord, } \\
\text { Norway, dinoflagel late bloom }\end{array}$ & $<0.01-0.12$ & $\begin{array}{l}\text { Paasche and } \\
\text { Ostergren, } 1980\end{array}$ \\
\hline & Diatom bloom & $0.11-0.38$ & \\
\hline Ice-edge diatom bloom & Mestern Ross Sea & $0.45-0.73$ & Smith and Nelson, 1985 \\
\hline Natural populations & Spring diatom blooms in Barents Sea & $0.05-0.34$ & Rey and Skjoldal, 1987 \\
\hline Natural populations & Southern California Bight & $0.011-0.22$ & This study \\
\hline
\end{tabular}


the subsurface chlorophyll maximum (Redalje, 1983). If all the PSi were in the phytoplankton, the ratio $\mathrm{PSi} /$ phytoplankton carbon might be in the range $0.011-0.023$ by atoms, based on Redalje's chlorophyll/carbon ratios and the mean PSi/chlorophyll ratios. These ratios are about an order of magnitude lower than the $\mathrm{Si} / \mathrm{C}$ ratios of diatom cultures. Brzezinski (1985), for example, found a mean ratio $\mathrm{PSi} / \mathrm{POC}$ by atoms of 0.13 for 27 species of diatoms in laboratory culture. This suggests that silicious plankton comprised only $10-20 \%$ of the plankton stocks in the Bight.

The ratio of PSi/chlorophyll $a$ may be of interest in field work. The overall mean ratio here was $0.85 \pm 0.69 \mu$ moles $\mathrm{Si} / \mu \mathrm{g}$ chlorophyll and 0.45 in the chlorophyll maximum (Table II). In Oslofjord, in the period 3 March to 6 June, 1978, we estimate a similar ratio, <0.71 in the upper $8 \mathrm{~m}$ depth range based on information in Paasche and Ostergren (1980). PSi/Chl ratios for many diatom cultures are less than this value. For example the range of values for Ditylum brightwelli was 0.18 to 0.46 (Eppley et al., 1967; Strickland et al., 1969), and for Skeletonema costatum the ratio varied with irradiance from 0.05-0.24 (Davis, 1976) and with dilution rate under Si-limition from 0.13 to 1.6 (Harrisonet al., 1976). Thus our PSi/chlorophyll ratios of suspended particles are high compared with diatom cultures.

The photosynthetic pigment fucoxanthin is found in several of the algal classes, including those containing the coccolithophorids, diatoms, silicoflagellates, chrysomonads, and other small flagellates within the class Prymnesiophyceae (Taylor, 1980). Fucoxanthin is not a unique label for silicious phytoplankton and would not label radiolarians except those with fucoxanthin-containing symbionts. Thus the correlation of PSi with fucoxanthin is expected to be imperfect, but perhaps to exceed that for chlorophyll. The fucoxanthin/chlorophyll $a$ ratio of diatoms is about 0.63 (W. Gieskes, personal communication; Gieskes and Kraay, 1983). Only three samples showed ratios $>0.4$ in this study. Two of these were collected below the chlorophyll maximum layer and one within it. The PSi/POC ratios for these three samples were $0.027,0.072$ and 0.072 , respectively. These ratios are low compared to flejan falta de información sobre el nano- y microplancton.

PSi vs. otros componentes del material particulado

Los resultados de las correlaciones que se encontraron entre PSi y POC, PON, clorofila y producción primaria (Tabla III), y no así con las concentraciones de ácido silícico disuelto, sugieren que la abundancia de diatomeas silícicas así como otro plancton también silícico puede variar independientemente de la concentración de ácido silícico en el ambiente. Las correlaciones no fueron consistentes entre cruceros (Tabla III) y fueron más altas para la profundidad de máxima clorofila subsuperficial.

La razón de PSi/POC ha sido reportada en estudios de campo previos (Tabla V). Los trabajos más intensos son aquellos de Copin-Montegut y Copin-Montegut (1978) para varias regiones del océano mundial; estudios de florecimiento de plancton en el fiordo de Oslo (Paasche y Ostergren, 1980) y florecimientos de diatomeas en el Antártico (Wilson et al., 1986; Smith y Nelson, 1985). Como en cultivos de diatomeas, la razón de $\mathrm{PSi} / \mathrm{POC}$ en florecimientos de diatomeas puede ser 0.3 o más por moles (Tabla $\mathrm{V}$ ). La razón es más baja en aguas oligotróficas reportadas por Lisitzin (1967), Copin-Montegut y Copin-Montegut (1978) y el presente estudio (Tabla V). El valor promedio de 0.047 encontrado aquí está en el rango observado en aguas oligotróficas y es el mismo valor promedio encontrado en aguas superficiales del mar de Barents por Rey y Skjoldal (1987). El fitoplancton comprende una alta proporción de material particulado en el nivel de máxima clorofila más que sobre la zona eufótica en la región del presente estudio (Eppley et al., 1977). Esto puede explicar la alta correlación de PSi con POC, PON, clorofila $a$ y producción primaria encontrada en el nivel de máxima clorofila (Tabla III). Las razones promedio de PSi a PON y clorofila $a$, aunque no para POC, en el máximo de clorofila también fueron más altas que para todas las muestras consideradas en conjunto (Tabla II).

La razón clorofila/carbono fitoplanctónico en el área de estudio es 0.014-0.020 en peso en las aguas superficiales y $0.025-0.050$ 
diatom cultures and do not suggest that the particulate matter was dominated by diatoms, nor did the ratio of fucoxanthin to total phytoplankton xanthophylls for these samples (J. Nelson, unpublished).

\section{Opal production rate}

The rate of silicic acid incorporation into particulate matter can be measured accurately using stable $\mathrm{Si}$ isotopic tracers (Nelson, 1975; Nelson and Goering, 1977) and also with radiogermanium as a proxy tracer for Si (Azam and Chisholm, 1976). These are surely the methods of choice. For more approximate estimates, i.e., the expected rate of opal production, the product of the primary production rate of carbon and the PSi/POC ratio serves (for example, Spencer, 1983). Nelson (1975) considered the errors in this approximation. Problems arise when detritus influences either PSi or POC independently. Estimates of opal production rate are high if PSi is more heavily contaminated than POC with non-photosynthetic material and low if the reverse is true. Nelson and Smith (1986) found good agreement of this approximate method with the PSi tracer method in a diatom bloom in the Antarctic. In that case most of the particulate matter consisted of diatoms and the $\mathrm{PSi} / \mathrm{POC}$ ratio averaged 0.6. Depth integrated production rates in their study gave $\mathrm{PSi} / \mathrm{POC}$ production ratios $0.15-1.0$, mean 0.57 , consistent with the biomass ratio.

Nelson and Smith (1986) summarized the existing information on biogenic silica production rate under a square meter of sea surface. Areas included Ross Sea ice edge and Antarctic Circumpolar Current, Baja California, Peru and Northwest Africa upwelling regions, the Southeast Bering Sea in spring and Gulf Stream warm core rings. Highest mean production rates were $22-89 \mathrm{~m}^{\text {mole m}} \mathrm{m}^{-2} \mathrm{~d}-1$ in the upwelling areas and the Ross Sea ice edge. Lowest rates were in the Antarctic Circumpolar Current where the mean was 3.0 and the range 0.9-6.8. Our estimates of the expected rates of opal production for the Bight are similar (Table IV), with mean 2.2 and range $0.8-4.3 \mathrm{~m} \mathrm{~mole}^{-2} \mathrm{~d}^{-1}$.

It was concluded that, for this oligotrophic region, particulate organic silica is en el máximo subsuperficial de clorofila (Redalje, 1983). Si todo el PSi fuera fitoplanctónico, basados en las razones clorofila/carbono de Redalje y razones PSi/clorofila promedio; la razón PSi/carbono fitoplanctónico podría caer dentro del intervalo 0.011-0.023 en átomos. Estas razones son cerca de un orden de magnitud más bajas que las razones $\mathrm{Si} / \mathrm{C}$ de cultivos de diatomeas. Brzezinski (1985), por ejemplo, encontró una razón PSi/POC atómica promedio de 0.13 para 27 especies de diatomeas en cultivos de laboratorio. Esto sugiere que el plancton silícico comprende del $10-20 \%$ de las reservas planctónica en la región estudiada.

La razón fitoplanctónica $\mathrm{PSi} /$ clorofila a puede ser de interés en el trabajo de campo. La razón promedio general aquí fue de 0.85 o $0.69 \mu$ moles $\mathrm{Si} / \mu \mathrm{g}$ de clorofila y 0.45 en el máximo de clorofila (Tabla II). En el fiordo de Oslo, basados en la información de Paasche y Ostergren (1980) durante el periodo del 3 de marzo al 6 de junio, nosotros podemos estimar una razón similar, <0.71 sobre un rango de profundidad de $8 \mathrm{~m}$. Las $\mathrm{PS} i / \mathrm{Chl}$ para muchos cultivos de diatomeas son menores que este valor. Por ejemplo el rango de valores para Ditylum brightwelli fue 0.18 a 0.46 (Eppley et al., 1967; Strickland et al., 1969) y para Skeletonema costatum la razón varió con la irradiación de 0.05 a 0.24 (Davis,1976) y con la tasa de dilusión bajo condiciones limitantes de Si de 0.13 a 0.16 (Harrisonet al., 1976). Así nuestros valores para la razón PSi/clorofila de partículas suspendidas son altos comparados con los reportados para cultivos de diatomeas.

El pigmento fotosintético ficoxantina se encuentra en algunas clases de algas, incluyendo aquellas que contienen coccolitofóridos, diatomeas, silicoflageladas, chrysomonadales y otras flageladas pequeñas, entre ellas la clase Prymnesiophyceae (Taylor, 1980). La ficoxantina no es un indicador únicamente de fitoplancton silícico y no podría indicar radiolarios excepto aquellos que contienen simbiontes silícicos fitoplanctónicos. Así la correlación de PSi con ficoxantina se esperaba baja, pero sin embargo sobrepasó a aquella calculada para la clorofila. La razón ficoxantina/clorofila $a$ de diatomeas es cerca de 0.63 (W. Gieskes, comunicación personal; Gieskes y Kraay, 1983). Solamente tres muestras demostraron razones $>0.4$ en este estudio. Dos 
related to subsurface chlorophyll maximum. In general, particulate organic silica levels are low.

\section{ACKNOWLEDGEMENTS}

We thank D.M. Nelson, Oregon State University, and W.W.C. Gieskes, Netherlands Institute of Sea Research for providing guidance. Several colleagues at Scripps helped collect the cruise data and also have our gratitude: E. Stewart, P. Matrai, W.M. Balch, M. Vernet, R. Hood and J. Schmitt. We also thank Captain Beattie and the crew of the $\mathrm{R} / \mathrm{V}$ Sproul for much help. The work was supported by NSF grants OCE-86-13685 and OCE-84-16320.

\section{LITERATURE CITED}

Antia, N.J. and McAllister, C.D. (1963). Further measurements of primary production using a large volume plastic sphere. Limnol. Oceanogr., 8: 166-183.

Azam, F. and Chisholm, S.W. (1976). Silicic acid uptake and incorporation by natural marine phytoplankton populations. Limnol. Oceanogr., 21: 427-435.

Berger, W.H. (1976). Biogenous deep sea sediments: production, preservation and interpretation. In: J.P. Riley and R. Chester (eds.), Chemical Oceanography. Academic, London, pp. 265-388.

Booth, C.R. (1976). The design and evaluation of a measurement system for photosynthetically active quantum scalar irradiance. Limnol. Oceanogr., 21: 326-336.

Broecker, W.S. and Peng, T.H. (1982). Tracers in the Sea. Eldigio Palisades, N.Y., $690 \mathrm{pp}$.

Brzezinski, M.A. (1985). The Si:C:N ratio of marine diatoms: Interspecific variability and the effect of some environmental variables. $J$. Phycol., 21: 347-357. de éstas fueron recolectadas sobre el nivel de clorofila máxima y una en él. Las razones PSi/POC para estas tres muestras fueron $0.027,0.072$ y 0.072 , respectivamente. Estas razones son bajas comparadas a las obtenidas en cultivos de diatomeas y no sugieren que el material particulado estuviese dominado por diatomeas, ni tampoco ocurre con la razón de ficoxantina a las xantofilas totales para estas muestras (J. Nelson, no publicado).

\section{Tasa de producción de 6́palo}

La tasa de incorporación de ácido silícico en el material particulado puede ser medido exactamente usando el método de trazador isotópico estable del Si (Nelson, 1985; Nelsony Goering, 1977) y también con germanio radioactivo como un trazador aproximado de para Si (Azam y Chisholm, 1976). Estos son seguramente los métodos que se deben elegir.

Como una aproximación de la tasa esperada de producción de ópalo, se puede usar el producto de la tasa de producción primaria de carbono y la razón PSi/POC (por ejemplo, Spencer, 1983). Nelson (1975) consideró los errores de esta aproximación. Los problemas se plantean cuando el detritus influencía, ya sea PSi o POC independientemente.

Las estimaciones de la tasa de 6́palo son altas si PSi es más pesadamente contaminado con material no fotosintético que el POC y bajo si lo contrario es cierto. Nelson y Smith (1986) encontraron una buena correspondencia de este método de aproximación con el método de trazador de $\mathrm{Si}$ en un florecimiento de diatomeas en el Artico. En ese caso la mayor parte de la materia particulada consistió en diatomeas y el promedio de la razón PSi/POC fue de 0.6. Las tasas de producción calculadas integrando con la profundidad en su estudio dio razones de producción PSi/POC entre 0.15 y 1.0 con un valor promedio de 0.57 , consistente con la razón de biomasa.

Finalmente, se debe agregar que Nelson y Smith (1986) sintetizaron la información existente sobre la producción de sílice biogénico bajo un metro cuadrado de superficie marina. Estas áreas incluyeron el borde del hielo del Mar de Ross y la Corriente Circumpolar Antártica, las regiones de surgencia de 
Carlucci, A.F., Eppley, R.W. and Beers, J.R. (1986). Introduction to the Southern California Bight. In: R.W. Eppley (ed.), Plankton Dynamics of the Southern California Bight. Springer-Verlag, Berlin, pp. 1-12.

Copin-Montegut, C. and Copin-Montegut, G. (1978). The chemistry of particulate matter from the South Indian and Antarctic Ocean Deep-Sea Res., 25: 911-931.

Cullen, J.J. and Eppley, R.W. (1981). Chlorophyll maximum layers of the Southern California Bight and possible mechanisms of their formation and maintenance. Oceanol. Acta, 4: 23-32.

Cullen, J.J., Reid, F.M.H. and Stewart, E. (1982). Phytoplankton in the surface and chlorophyll maximum off Southern California in August, 1978. J. Plankton Res., 4: 665-694.

Davis, C.O. (1976). Continuous culture of marine diatoms under silicate limitation. II. Effect of light intensity on growth and nutrient uptake of Skeletonema costatum. J. Phycol., 12: 291-300.

Eppley, R.W. (1970). Part IV. Relationships of phytoplankton species distribution to the depth distribution of nitrate. In: J.D.H. Strickland (ed.), The Ecology of the Plankton off La Jolla, California, in the Period April through September 1967. Berkeley Univ. Calif. Press, pp. 43-49. (Bull. Scripps Inst. Oceanogr., v. 17.)

Eppley, R.W. and Holm-Hansen, O. (1986). Primary production in the Southern California Bight. In: R.W. Eppley (ed.), Plankton Dynamics of the Southern California Bight. Springer-Verlag, Berlin, pp. 176-215.

Eppley, R.W., Holmes, R.W. and Paasche, E. (1967). Periodicity in cell division and physiological behavior of Ditylum brightwellii, a marine diatom, during growth on light-dark cycles. J. Exptl. Mar. Biol. Ecol., 1: 191-208.

Eppley, R.W., Harrison, W.G., Chisholm, S.W. and Stewart, E. (1977). Particulate organic matter in surface waters off Southern California and its relationship to phytoplankton. J. Mar. Res., 35: 671-696.
Baja California, Perú y Noroeste de Africa, el Sureste del Mar de Bering en primavera $y$ nucleos templados de la Corriente del Golfo. Las tasas de producción promedio más altas fueron 22-89 m moles $\mathrm{m}^{-2} \mathrm{~d}^{-1}$ en las áreas de surgencia y el borde del hielo de Ross. Las tasa más bajas fueron en la Corriente Circumpolar Antártica donde el promedio fue 3.0 y el rango 0.9-6.8. Nuestras estimaciones de tasas esperadas de producción de ópalo para el área de estudio son similares (Tabla IV), con un promedio de $2.2 \mathrm{y}$ un rango $0.8-4.3 \mathrm{~m}$ mole $\mathrm{m}^{-2} \mathrm{~d}^{-1}$.

En conclusión se puede decir que en general el sílice orgánico particulado es bajo en esta región oligotrófica de la región adyacente al sur de California y su concentración se relaciona con el máximo de clorofila subsuperficial.

\section{AGRADECIMIENTOS}

Agradecemos a D.N. Nelson, Oregon State University, y W.W.C. Gieskes, Netherlands Institute of Sea Research, por su guía. A los colegas de Scripps que ayudaron en la recolecta de datos de crucero que también reciban nuestra gratitud: $E$. Stewart, $P$. Matrai, W.M. Balch, M. Vernet, R. Hoody J. Schmitt. También agradecemos al Capitán Beattie y la tripulación del R/V Sproul por su gran ayuda. El trabajo fue solventado por las donaciones OCE-86-13685 y OCE-84-16320 de NSF.

Traducido al español por el autor.

Garside, C. (1982). A chemiluminescent technique for the determination of nanomolar concentrations of nitrate and nitrite in seawater. Mar. Chem., 11: 159-167.

Gieskes, W.W.C. and Kraay, G.W. (1983). Dominance of Cryptophyceae during the phytoplankton spring bloom in the central North Sea detected by HPLC analysis of pigment. Mar. Biol., 75: 179-185.

Harrison, P.J., Conway, H.L. and Dugdale, R.C. (1976). Marine diatoms grown in chemostats under silicate or ammonium limitation. I. Cellular chemical composition and steady-state growth kinetics of Skeletonema costatum. Mar. Biol., 35: 177-186. 
Jackson, G.A. (1986). Physical oceanography of the Southern California Bight. In: R.W. Eppley (ed.), Plankton Dynamics of the Southern California Bight. Springer-Verlag, Berlin, pp. 13-52.

Krause, G.L., Schelske, C.L. and Davis, C.O. (1983). Comparison of three wet-alkaline methods of digestion of biogenic silica in water. Freshwater Biol., 13: 73-81.

Lisitzin, A.P. (1967). Basic relationship in distribution of modern siliceous sediments and their connection with climatic zonation. I.G.R. Staff translation. Int. Geol. Rev., 9: $631-652$.

Mantoura, R.F.C. and Llewellyn, C.A. (1983). The rapid determination of algal chlorophyll and carotenoid pigments and their breakdown products in natural waters by reverse-phase high performance liquid chromatography. Amal. Chim. Acta, 151: 297-314.

McAllister, C.D., Parsons, T.R., Stephens, K. and Strickland, J.D.H. (1961). Measurements of primary production in coastal sea water using a large-volume plastic sphere. Limnol. Oceanogr., 6: 237-258.

Mullin, M.M. (1986). Spatial and temporal scales and patterns. In: R.W. Eppley (ed.), Plankton Dynamics of the Southern California Bight. Springer-Verlag, Berlin, pp. 216-273.

Nelson, D.M. (1975). Uptake and regeneration of silicic acid by marine phytoplankton. Ph.D. Thesis, University of Alaska, Fairbanks, $157 \mathrm{pp}$.

Nelson, D.M. and Goering, J.J. (1977). A stable isotope tracer method to measure silicic acid uptake by marine phytoplankton. Anal. Biochem., 78: 139-147.

Nelson, D.M. and Smith, W.O. (1986). Phytoplankton bloom dynamics of the western Ross Sea ice edges. II. Mesoscale cycling of nitrogen and silicon. Deep-Sea Res., 33: 1389-1412.

Nelson, J.R. (1986). Phytoplankton carotenoids as organic tracers in marine particulate organic matter. Ph.D. Thesis, University of California, San Diego, California, 309 pp.
Paasche, E. (1980). Silicon content of five marine plankton diatom species measured with a rapid filter method. Limnol. Oceanogr., 23: 481-496.

Paasche, E. and Ostergren, G. (1980). The annual cycle of plankton diatom growth and silica production in the inner Oslofjord. Limnol. Oceanogr., 25: 481-496.

Pelaez, J. and McGowan, A. (1986). Phytoplankton pigment patterns in the California Current as determined by satellite. Limnol. Oceanogr., 31: 927-950.

Redalje, D.G. (1983). Phytoplankton carbon biomass and specific growth rates determined with a labeled chlorophyll technique. Mar. Ecol. Progr. Ser., 11: 217-225.

Rey, F. and Skjoldal, H.R. (1987). Consumption of silicic acid below the euphotic zone by sedimenting diatom blooms in the Barents Sea. Mar. Ecol. Progr. Ser., 36: 307-312.

Sackett, W. and Arrhenius. G. (1962). Distribution of aluminium species in the hydrosphere. I. Aluminium in the ocean. Geochium. Cosmochim. Acta, 26: 955-968.

Sharp, J.H. (1974). Improved analysis for "particulate" organic carbon and nitrogen from seawater. Limnol. Oceanogr., 19: 984-989.

Smith, R.C. and Baker, K.S. (1982). Oceanic chlorophyll concentrations determined by satellite (Nimbus-7 coastal zonc color scanner). Mar. Biol., 66: 269-279.

Smith, W.O. and Nelson, D.M. (1985). Phytoplankton bloom produced by a receding ice edge in the Ross Sea: spatial coherence with the density field. Science, 227: 163-166.

Spencer, C.P. (1983). Marine biogeochemistry of silicon. In: S.R. Aston (ed.), Silicon Geochemistry and Biogeochemistry. Academic, London, pp. 101-141.

Strickland, J.D.H. (1965). Production of organic matter in primary stages of the marine food chain. In: J.P. Riley and G. Skirrow (eds.), Chemical Oceanography, Vol. 1, Academic, London, pp. 478-610. 
Strickland, J.D.H. and Parsons, T.R. (1972). A practical handbook of seawater analysis. Fish Res. Board Can., Bull. 167, 2nd Ed., 310pp.

Strickland, J.D.H., Holm-Hansen, O., Eppley, R.W. and Linn, R.J. (1969). The use of a deep tank in plankton ecology. I. Studies of the growth and composition of phytoplankton crops at low nutrient level. Limnol. Oceanogr., 14: 23-34.

Taylor, F.J.R. (1980). Basic biological features of phytoplankton cells. In: I. Morris (ed.), The Physiological Ecology of Phytoplankton. Univ. Calif. Press, Berkeley, pp. 3-55.
Tont, S.A. (1987). Variability of diatoms species populations; from days to years. J. Mar. Res., 45: 985-1006.

Wilson, D.L., Smith, W.O. and Nelson, D.M (1986). Phytoplankton bloom dynamics of the western Ross Sea ice edge. I. Primary production and species-specific production. Deep-Sea Res., 33: 1375-1387. 